\title{
Evaluation of Quality Compost Prepared from Paddy Straw and Distillery Effluent for Effect on Growth of Wheat (Triticum aestivum)
}

\author{
Pankaj Kumari, Suman Chaudhary*, Tanvi, Rinku Dhanker and Sneh Goyal \\ Department of Microbiology, CCS Haryana Agricultural University, Hisar-125004, \\ Haryana, India \\ *Corresponding author
}

\section{A B S T R A C T}

\begin{tabular}{|l|}
\hline K e y w o r d s \\
$\begin{array}{l}\text { Co-composting, Paddy } \\
\text { straw, Distillery effluent, } \\
\text { Compost and plant } \\
\text { growth, Wheat crop }\end{array}$ \\
\hline Article Info \\
\hline $\begin{array}{l}\text { Accepted: } \\
10 \text { March } 2018 \\
\text { Available Online: } \\
10 \text { April } 2018\end{array}$ \\
\hline
\end{tabular}

\section{Introduction}

Paddy straw is a major agricultural waste in rice producing countries including India (Reinhard et al., 2001). Paddy straw is a major agricultural waste in rice producing countries. About 95 million tons of rice residues are produced in the Indo-Gangetic plains, which is about $39 \%$ of total crop residues generated (Sidhu et al., 2003). Distillery effluent is an industrial dark brown organic material having extremely high biological oxygen demand (BOD), chemical oxygen demand (COD), inorganic solids and having acidic $\mathrm{pH}$ (Shin et al., 1992, Biradar, 2005, Saha et al., 2005, Srivastava et al., 2012). It is considered as one
The main objective of present investigation was to study the effect of quality compost prepared from paddy straw and distillery effluent on the growth of wheat crop. Three best composts 1,2and 3 weretaken for the growth of wheat crop and different treatments were made by amending soil with different concentrations of compost and recommended dose of fertilizers. Different parameters like root, shoot weight and length, N, P, K uptake by maxit at 90 days of sowing and total N, P, K of soil after harvesting were studied. The maximum root and shoot length were 15.92 and $36.20 \mathrm{~cm}$ respectively in T9. The same effect was seen with root and shoot weight, it was also maximum in T9 i.e. The dry matter yield and $\mathrm{N}$ (41.75), $\mathrm{P}$ (51.24), $\mathrm{K}$ (35.87) $\mathrm{mg} / \mathrm{plant}$ uptake of wheat was maximum in $\mathrm{T} 9$ with the application of $100 \%$ RDF along with compost prepared with $30 \%$ distillery effluent and microbial consortia (compost 2). The total $\mathrm{N}(0.038 \%), \mathrm{P}(532 \mathrm{mg} / \mathrm{Kg}$ ) was maximum in T9 while $\mathrm{K}(0.344 \%)$ of soil after harvesting of crop was maximum in T13. 
agricultural residue generated in rice fields and distillery effluent is an industrial waste, produced by molasses-based distilleries (Sidhu et al., 2003).

Composting can be an alternative to recycle such organic wastes along with winery and distillery effluent since it convert them into organic manures which can be used in agricultural practices (Bustamante et al., 2007; 2008). Composting is a process of transforming biologically or biochemically, the organic materials into amorphous humus like substances (under optimum temperature, moisture and aeration conditions) that can be handled, stored and applied to land without harmful environmental impacts (GallardoLarva and Nogades, 1987). Also composting or addition of compost may enhance soil organic matter content, thus soil fertility besides bioremediation, and thus it is believed to be one of the most cost-effective methods for soil health improvement (Chen et al., 2017). There are so many diverse strategies for soil bioremediation through composting which are direct composting in field, compost addition, and incorporation of bulking agent, bio-augmentation and application of surfactants. Researchers mostly apply a single or a combination of these strategies to achieve their goals. Organic wastes from agricultural and industrial practices are often selected as the initial composting materials to reduce the costs during soil bioremediation. Also use of these organic wastes for soil remediation is also beneficial in minimizing time and money in their treatment and storage. Organic matter used for composting is helpful in improving soil quality and fertility (Pedra et al., 2007).

If paddy straw having high $\mathrm{C} / \mathrm{N}$ ratio is mixed with low $\mathrm{C} / \mathrm{N}$ ratio industrial waste and cocomposted, the resulting compost, if use as organic manure, reduce the environmental pollution, substitute chemical fertilizers and maintain the soil health (Bustamante et al.,
2010). Since it transforms wastes into organic manures, which can be used in agricultural soil to improve growth of various crops. These organic wastes component of compost are typically rich in organic matter having high levels of nitrogen (N) and phosphorus (P) which are required for growth of plant (Eghball and Gilley, 1999; Parkinson et al., 2004).

So keeping in view the harmful impacts of paddy straw and distillery effluents to the environment and day by day decreasing soil quality due to application of chemical fertilizers, the present study was carried out with the idea of application of compost prepared from paddy straw and distillery effluent like organic waste in soil to enhance the crop quality, thus evaluation of its effects on growth of wheat crop.

\section{Materials and Methods}

\section{Compostable material}

Rice straw was collected from farmer's fields of village Gujjar Bara, Dist. Narnond (Haryana) India. The distillery effluent (treated) was collected from Associated Distilleries Ltd. Hisar. The cattle dung was collected from Animal Science Department, COBS\&H, CCS HAU, Hisar.

\section{Compost selection}

Compost was prepared from paddy straw, distillery effluent treated in different concentrations and cattle dung along with microbial consortium and it was analysed for various quality parameters like $\mathrm{C} / \mathrm{N}$ ratio, $\mathrm{CO}_{2}$ evolution, water soluble carbon, humic substances, and wheat germination index under laboratory conditions.

Based upon different quality parameters following three best composts were selected: 
Compost 1. (Paddy straw $+20 \%$ Distillery Effluent $+10 \%$ Cattle dung + microbial consortia)

Compost 2. (Paddy straw $+30 \%$ Distillery Effluent $+10 \%$ Cattle dung + microbial consortia)

Compost 3. (Paddy straw $+40 \%$ Distillery Effluent $+10 \%$ Cattle dung + microbial consortia)

All three selected composts were dark brown in colour and having neutral $\mathrm{pH}$.

Effect of quality compost on growth of wheat

As there was no phytotoxicity seen in laboratory conditions and it was further evaluated for effect on growth of wheat under pot house conditions. Soil for pot house experiment was collected from field of Balsmand, Hisar and it was analysed for presence of $\mathrm{N}, \mathrm{P}, \mathrm{K}$ and total organic carbon.

After analysing soil and different parameters of compost, the quality compost was checked for its influence on growth of wheat crop under pot house experiment.

Compost was amended @ 5 ton/hectare in the upper layer of soil $(0-15 \mathrm{~cm})$ in pots. For this experiment wheat seeds (var. WH 711) used were obtained from CCS HAU, Hisar farm.

Distinct treatments were designed by changing amount of RDF (recommended dose of fertilizer which is $120 \mathrm{~kg} \mathrm{~N}, 60 \mathrm{~kg} \mathrm{P}, 60 \mathrm{~kg} \mathrm{~K}$ and $25 \mathrm{~kg} \mathrm{Zn}$ per hectare for wheat).

One control was taken without any RDF and three quality composts were applied to pots with different combinations of recommended dose of fertilizers i.e. $0 \%, 50 \%, 75 \%$ and $100 \%$ respectively.
The following different parameters of wheat crop were observed

\section{Quantitative parameters}

Root weight and length were measured.

Shoot weight and length were also observed.

\section{Qualitative parameters}

Total N, P, K uptake by wheat crop after 90 days of sowing was calculated.

Total N, P, K level of soil was also observed after crop harvest.

Total Nitrogen content was determined by Kjeldahl's method (Bremner and Mulvaney, 1982). The total phosphorus was estimated by the method of John (1970).

Total Potassium was calculated on flame photometer by direct feeding given by Jackson, 1973.

\section{Results and Discussion}

\section{Initial chemical analysis of soil}

The initial analysis of soil was done for pot experiment. The soil was sandy with $0.15 \%$ organic carbon and total $\mathrm{N}, \mathrm{P}$ and $\mathrm{K}$ was $0.016 \%, 260 \mathrm{mg} / \mathrm{Kg}$ and $0.25 \%$ respectively.

\section{Effect of quality compost on plant health and soil health}

The table 1 shows the effect of three quality compost on wheat root, shoot length under pot house conditions. Root length $(15.92 \mathrm{~cm})$ was highest in treatment T9 having compost 2 (@5t/ha) + (100\% RDF) and was lowest (2.21 $\mathrm{cm}$ ) in T1 (control) having only soil. Shoot length was maximum $(36.20 \mathrm{~cm})$ in the same treatments and was lowest $(16.13 \mathrm{~cm})$ in control without any fertilizer (Fig. 1). 
Following treatments were designed

\begin{tabular}{|c|c|}
\hline Treatment No. & Treatment \\
\hline T1 & Soil(0\% RDF) \\
\hline T2 & Soil+Compost 1 (@ 5t/ha)+0\% RDF \\
\hline T3 & Soil+ Compost 1 (@ 5t/ha)+50\% RDF \\
\hline T4 & Soil+ Compost 1 (@ 5t/ha)+75\% RDF \\
\hline T5 & Soil+ Compost 1 (@ 5t/ha)+100\% RDF \\
\hline T6 & Soil+Compost 2 (@ 5t/ha)+0\% RDF \\
\hline T7 & Soil+Compost 2 (@ 5t/ha)+50\% RDF \\
\hline T8 & Soil+Compost 2 (@ 5t/ha)+75\% RDF \\
\hline T9 & Soil+ Compost 2 (@ 5t/ha) + 100\% RDF \\
\hline T10 & Soil+Compost 3 (@ 5t/ha)+0\% RDF \\
\hline T11 & Soil+Compost 3 (@ 5t/ha)+50\% RDF \\
\hline T12 & Soil+Compost 3 (@ 5t/ha)+75\% RDF \\
\hline T13 & Soil+ Compost 3 (@ 5t/ha)+100\% RDF \\
\hline
\end{tabular}

Table.1 Effect of compost on length of wheat (Var-WH 711) at 90 days after sowing

\begin{tabular}{|c|c|c|c|c|}
\hline $\begin{array}{l}\text { Sr. } \\
\text { No. }\end{array}$ & Treatments & $\begin{array}{l}\text { Root length } \\
(\mathrm{cm})\end{array}$ & $\begin{array}{l}\text { Shoot } \\
\text { length (cm) }\end{array}$ & $\begin{array}{l}\text { Total length } \\
\text { (cm) }\end{array}$ \\
\hline T1. & $0 \%$ RDF (Control) & 2.20 & 16.13 & 18.33 \\
\hline T2. & Compost 1 (@ 5t/ha)+0\% RDF & 9.13 & 30.75 & 39.88 \\
\hline T3. & Compost1 $(@ 5 t / h a)+50 \%$ RDF & 13.26 & 32.06 & 45.32 \\
\hline T4. & Compost 1 (@ 5t/ha)+75\% RDF & 13.94 & 33.16 & 47.10 \\
\hline T5. & Compost 1 (@ 5t/ha)+100\% RDF & 14.81 & 34.30 & 49.11 \\
\hline T6. & Compost 2 (@ 5t/ha)+0\% RDF & 13.35 & 31.21 & 44.56 \\
\hline T7. & Compost2(@5t/ha)+50\% RDF & 14.60 & 32.43 & 47.03 \\
\hline T8. & Compost 2(@ 5t/ha)+75\% RDF & 15.02 & 35.31 & 51.33 \\
\hline T9. & Compost $2(@$ 5t/ha)+100\% RDF & 15.92 & 36.20 & 52.12 \\
\hline T10. & Compost 3 (@ 5t/ha)+0\% RDF & 12.26 & 30.90 & 43.16 \\
\hline T11. & Compost3 (@5t/ha)+50\% RDF & 13.10 & 32.50 & 45.60 \\
\hline T12. & Compost 3 (@ 5t/ha)+75\% RDF & 15.33 & 34.30 & 49.63 \\
\hline T13. & Compost 3 (@ 5t/ha)+100\% RDF & 14.66 & 36.05 & 50.71 \\
\hline \multicolumn{2}{|c|}{ C. D. at $5 \%$ level of significance } & 0.14 & 0.06 & 0.08 \\
\hline
\end{tabular}


Table.2 Effect of quality compost on root and shoot dry weight of wheat (Var- WH 711) at 90 days after sowings

\begin{tabular}{|c|c|c|c|c|}
\hline Sr. No. & Treatments & $\begin{array}{c}\text { Root dry } \\
\text { weight (mg / } \\
\text { pot) }\end{array}$ & $\begin{array}{c}\text { Shoot dry } \\
\text { weight (mg / } \\
\text { pot) }\end{array}$ & $\begin{array}{l}\text { Total dry } \\
\text { weight } \\
\text { (mg / pot) }\end{array}$ \\
\hline T1. & 0\% RDF (Control) & 96 & 212 & 308 \\
\hline T2. & Compost 1 (@ 5t/ha)+0\% RDF & 264 & 838 & 1102 \\
\hline T3. & Compost1 (@ 5t/ha)+50\% RDF & 338 & 1046 & 1384 \\
\hline T4. & Compost 1 (@ 5t/ha)+75\% RDF & 388 & 1062 & 1450 \\
\hline T5. & $\begin{array}{l}\text { Compost } 1 \text { (@5t/ha })+100 \% \\
\text { RDF }\end{array}$ & 410 & 1074 & 1484 \\
\hline T6. & Compost 2 (@ 5t/ha)+0\% RDF & 280 & 972 & 1252 \\
\hline T7. & Compost $2(@$ t $/$ ha $)+50 \%$ RDF & 296 & 1038 & 1334 \\
\hline T8. & Compost 2 (@ 5t/ha)+75\% RDF & 442 & 1386 & 1828 \\
\hline T9. & $\begin{array}{l}\text { Compost 2（@5t/ha })+100 \% \\
\text { RDF }\end{array}$ & 499 & 1399 & 1898 \\
\hline T10. & Compost 3 (@ 5t/ha)+0\% RDF & 339 & 867 & 1206 \\
\hline T11. & Compost 3 (@ 5t/ha)+50\% RDF & 394 & 892 & 1286 \\
\hline T12. & Compost 3 (@ 5t/ha)+75\% RDF & 442 & 1186 & 1628 \\
\hline T13. & $\begin{array}{l}\text { Compost 3(@ } @ \text { t/ha })+100 \% \\
\text { RDF }\end{array}$ & 466 & 1204 & 1670 \\
\hline \multicolumn{2}{|c|}{ C. D. at $5 \%$ level of significance } & 7.85 & 23.96 & 21.67 \\
\hline
\end{tabular}

Table.3 Total N, P, K level of soil after crop harvest

\begin{tabular}{|c|c|c|c|c|}
\hline Sr. No. & Treatments & Total N (\%) & Total P(mg/Kg) & Total K (\%) \\
\hline T1. & $0 \% \mathrm{RDF}$ & 0.016 & 260 & 0.248 \\
\hline T2. & Compost 1 (@5t/ha)+0\% RDF & 0.024 & 423 & 0.288 \\
\hline T3. & Compost 1 (@ 5t/ha)+50\% RDF & 0.028 & 430 & 0.309 \\
\hline T4. & Compost 1 (@5t/ha)+75\% RDF & 0.034 & 506 & 0.317 \\
\hline T5. & Compost1 (@ 5t/ha)+100\% RDF & 0.035 & 510 & 0.326 \\
\hline T6. & Compost2 (@5t/ha)+0\% RDF & 0.029 & 460 & 0.300 \\
\hline T7. & Compost $2(@ 5 \mathrm{t} / \mathrm{ha})+50 \% \mathrm{RDF}$ & 0.031 & 490 & 0.316 \\
\hline T8. & Compost $2(@$ tt/ha)+75\% RDF & 0.035 & 525 & 0.318 \\
\hline T9. & Compost 2 (@5t/ha)+100\% RDF & 0.041 & 532 & 0.320 \\
\hline T10. & Compost 3 (@5t/ha)+0\% RDF & 0.030 & 464 & 0.293 \\
\hline T11. & Compost 3 (@5t/ha)+50\% RDF & 0.034 & 492 & 0.326 \\
\hline T12. & Compost3 (@ 5t/ha)+75\% RDF & 0.039 & 517 & 0.342 \\
\hline T13. & Compost 3 (@5t/ha)+100\% RDF & 0.038 & 523 & 0.344 \\
\hline \multicolumn{2}{|c|}{ C. D. at $5 \%$ level of significance } & N.S. & 17.167 & 0.071 \\
\hline
\end{tabular}


Fig.1 Effect of quality compost on growth of wheat (Var- WH 711) at 90 days after sowing

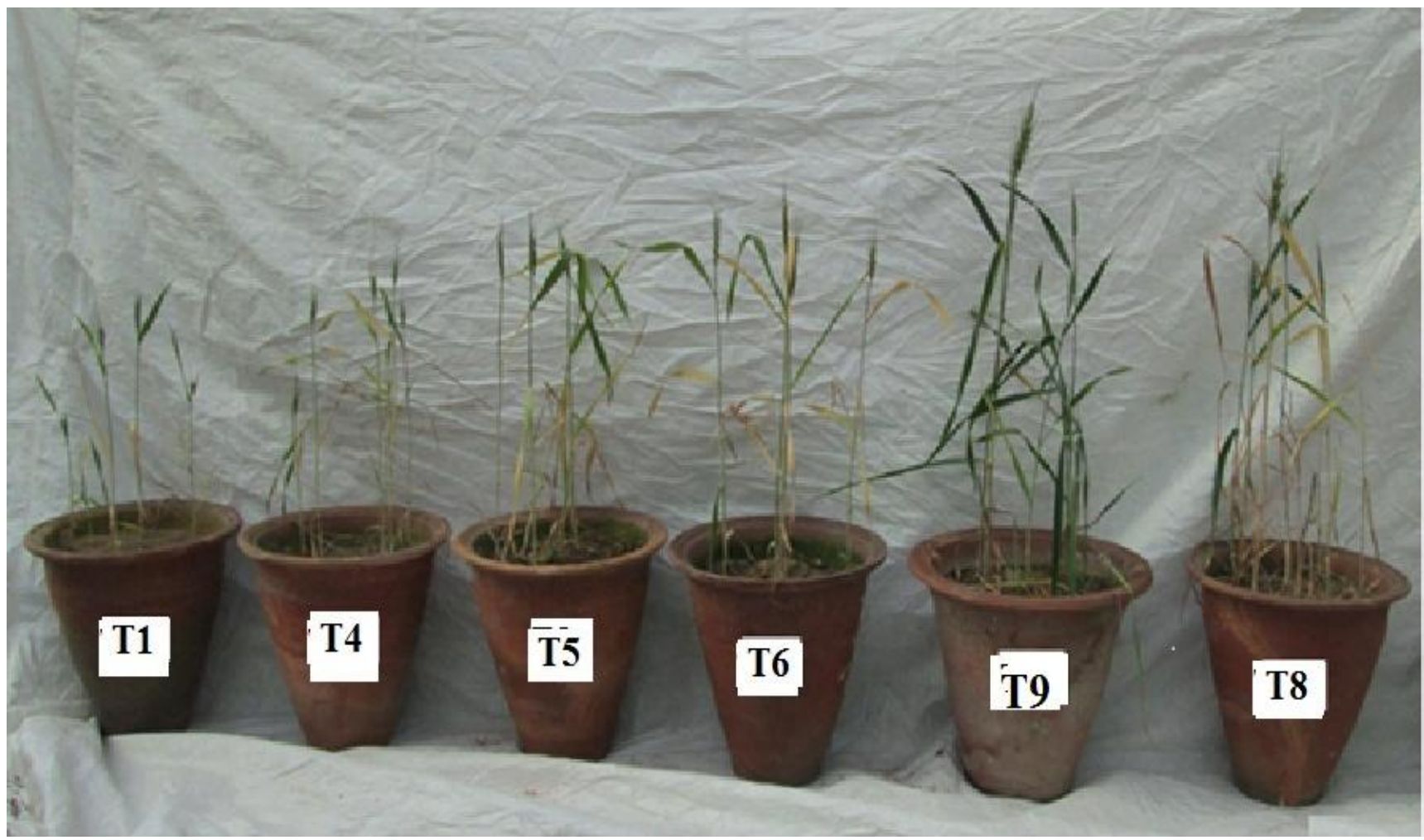

Fig.2 N uptake by wheat plants (WH-711) after crop harvest

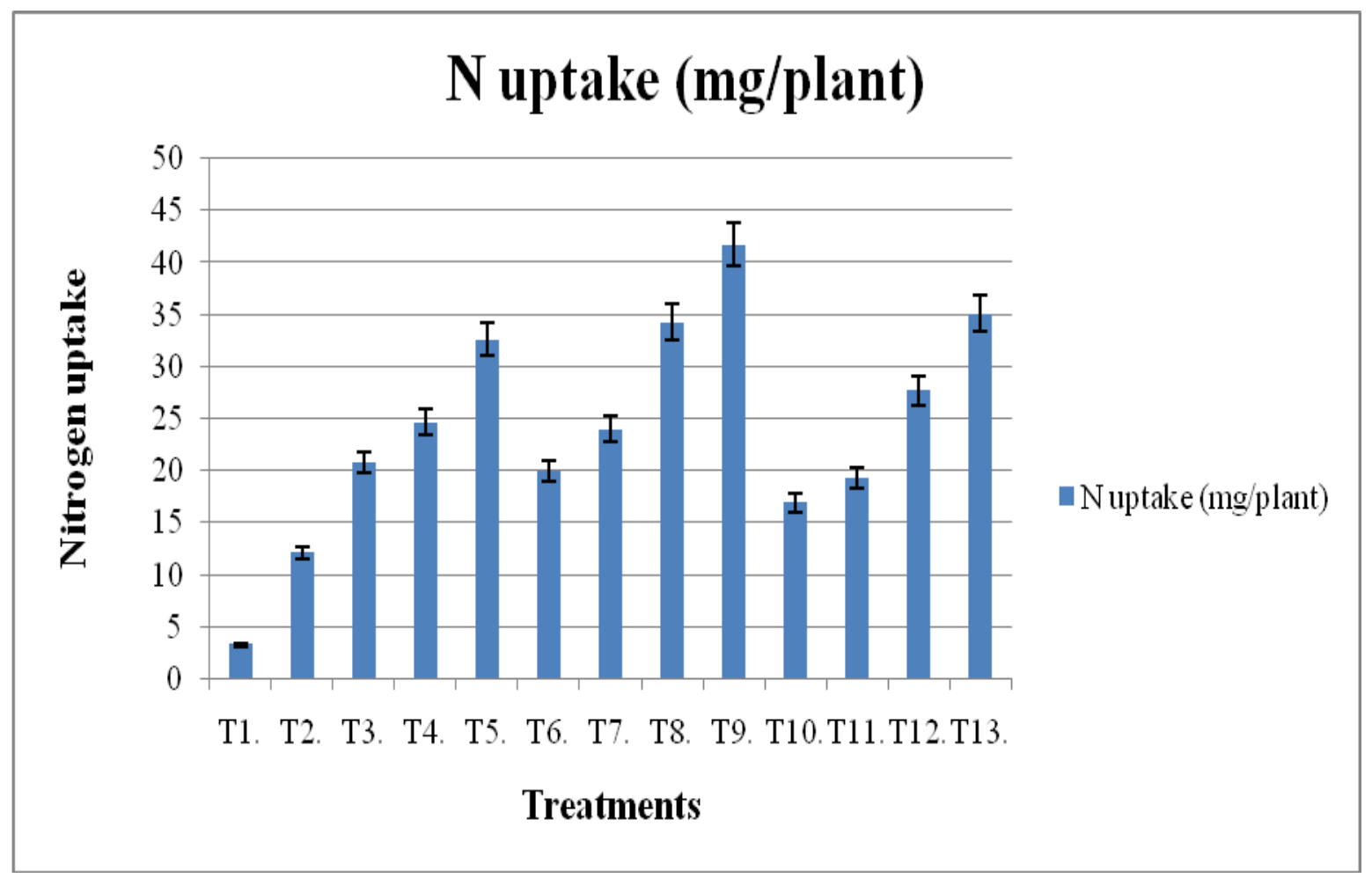


Fig.3 P uptake by wheat plants (WH-711) after crop harvest

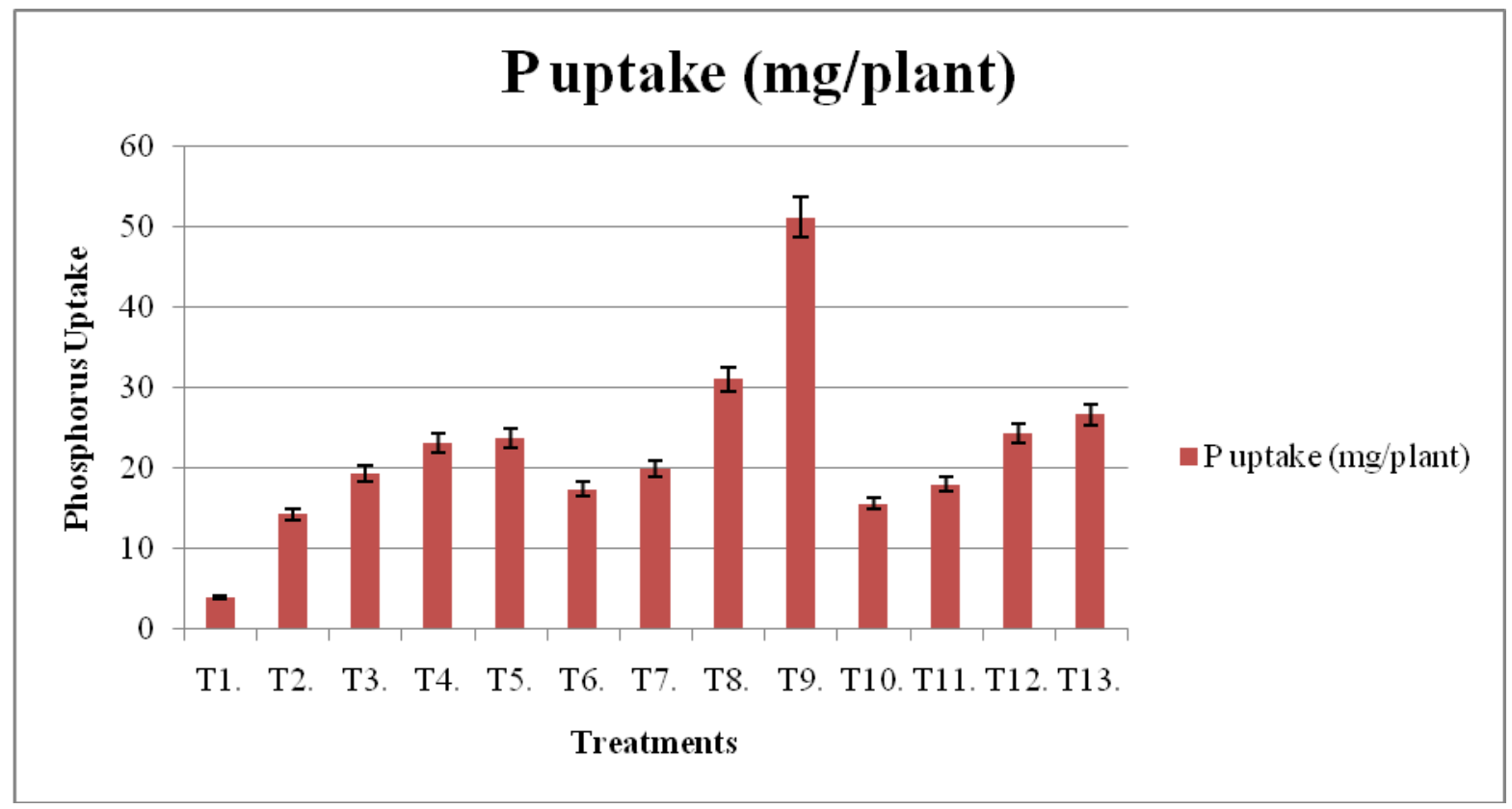

Fig.4 K uptake by wheat plants (WH-711) after crop harvest

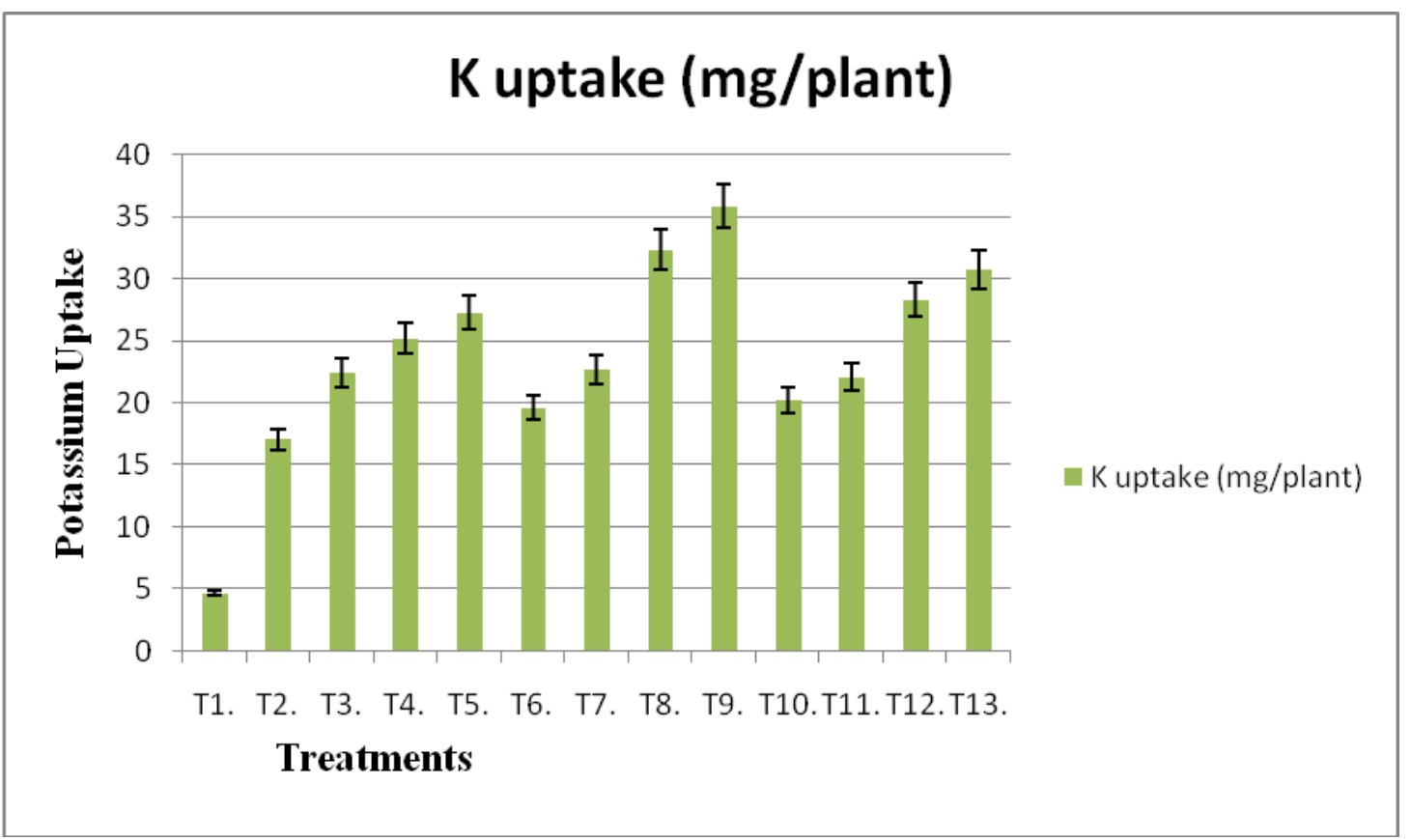

Root and shoot dry weight of wheat plants were also observed after 90 days of sowing. Root dry weight was maximum (499 mg/ pot) in treatment T9 having compost $2+100 \%$ RDF. The shoot dry weight and total dry weight were also maximum in the treatment T9; it was 1399 and $1898 \mathrm{mg} /$ pot respectively (Table 2). The both were minimum in the treatment T1 (control) and was 96 and 212 mg per pot of root and shoot respectively. 
Nutrient $(\mathrm{N}, \mathrm{P}, \mathrm{K})$ uptake in plants after 90 days of sowing are presented in Figure 2, 3 and 4 respectively. Highest N, P and K uptake was $41.75, \quad 51.24$ and $35.87 \mathrm{mg} /$ plant respectively in treatment $\mathrm{T} 9$ having compost $2+100 \%$ RDF.

Soil was analyzed for total N, P and K after harvest of wheat crop. Total $\mathrm{P}$ and $\mathrm{K}$ increased significantly over control, while increase in total $\mathrm{N}$ was not significant. Total $\mathrm{N}$ and $\mathrm{P}$ was maximum in treatment T9having compost 2 (@5 t/ha) + 100\% RDF, While total $\mathrm{K}(\%)$ was maximum in treatment T13 having compost $3 @ 5 \mathrm{t} / \mathrm{ha})+100 \% \mathrm{RDF}$ (Table 3).

The impact of paddy straw and distillery effluent compost on plant growth parameters in wheat (var. WH-711) was evaluated under pot house conditions at 0\% RDF (control) and it was compared with treatment having compost @ 5 t/ha + 0, 50, 75 and $100 \%$ RDF respectively and it was found that the application of compost@5t/ha resulted into more uptake of $\mathrm{N}, \mathrm{P}$ and $\mathrm{K}$ by wheat plants. Various plant growth parameters viz., root length, shoot length, plant weight were also significantly affected by compost application alone or in combination with inorganic fertilizers. The evaluation of rhizospheric soil after crop harvest also showed the improvement in soil organic N, P and K contents. Showing thereby that the application of $5 \mathrm{t} / \mathrm{ha}$ compost in sandy soil will improve the crop quality and soil health. These results were in agreement with finding of Siddiqui et al., (2008), as the plant growth parameters were significantly higher when paddy straw compost was tested on green bean under pothouse. The paddy straw compost fortified with Trichoderma harzianum reduced the disease intensity of root rot in green bean and also promoted plant height, fresh and dry weight. Tahir et al., (2006) also revealed that organic compost enriched with $25 \%$ recommended dose of fertilizer and inoculated with PGPR was more effective in improving growth and yield of tomato as compared to full dose of $\mathrm{N}$ fertilizer.

In an another study carried out by Sadaf et al., (2017), the total carbon and mineral nitrogen content of wheat crop were increased 21 and $106 \%$ higher respectively when compare with control by application of biochar and chemical fertilizers $(\mathrm{CF})$. Co-application of biochars and $\mathrm{CF}$ treatments increased the biological yield of wheat crop with highest increment in nutrient biochars farmyard manure or poultry manure (29 or $26 \%$ ), than structural biochars wood chips and kitchen waste (15 and 13\%), respectively.

To sustain the soil fertility, the integrated use of inorganic fertilizer with organic manure is the need of the day. These studies indicate that paddy straw and distillery effluent can be co-composted and converted into a product, which can benefit plant growth and soil health. The findings of above study should be evaluated at the field conditions before this technology is transmitted to the farmers.

Application of compost prepared by paddy straw and $30 \%$ distillery effluent along with cattle dung and microbial consortium and $100 \%$ recommended dose of fertilizer@ $5 \mathrm{t} /$ ha, resulted into improved wheat yield and crop quality like more uptake of nutrients like $\mathrm{N}, \mathrm{P}$ and $\mathrm{K}$. Also there was improvement in soil health as there was increment in soil nutrients. Total $\mathrm{N}, \mathrm{P}$ and $\mathrm{K}$ was up to $0.038 \%, 532 \mathrm{mg} / \mathrm{Kg}$ and $0.344 \%$ respectively in comparison to initial soil $\mathrm{N}, \mathrm{P}$ and $\mathrm{K}$ $0.016 \%, 260 \mathrm{mg} / \mathrm{Kg}$ and $0.25 \%$ respectively.

\section{Acknowledgement}

We greatly acknowledged the Department of Microbiology, College of Basic Sciences and Humanities, CCSHAU Hisar, Haryana, India 
for the help and support during execution of the experiments. We are highly thankful to the anonymous reviewers for their comments and suggestions which greatly enhanced the quality of old version.

\section{References}

Biradar A., 2005. Post-Anaerobic Treatment of Distillery Spent wash. Ph.D. Thesis, Indian Institute of Technology, Bombay (India).

Bremner J.M., and Mulvaney C.S. 1982. Nitrogen - Total. In: Methods of Soil Analysis (A. L. Page ed.) Agronomy Monograph 9, Part 2, 2nd ed. American Society of Agronomy, Madison, WI, pp: 595-624.

Bustamante M.A., Paredes C., Marhuenda Egea F.C., Perez-Espinosa A., Bernal M.P. and Moral R. 2008. Cocomposting of distillery wastes with animal manures: carbon and nitrogen transformations in the evaluation of compost stability. Chemosphere. 72: 551-557.

Bustamante M.A., Paredes C., Moral R., Moreno-Caselles J., Perez-Murcia M.D., Perez-Espinosa A. and Bernal M.P. 2007.Co-composting of distillery and winery wastes with sewage sludge. Water Science Technology. 56: 187192.

Bustamante M.A., Said-Pullicino D., Paredes C., Cecilia J.A. and Moral R. 2010. Influences of winery - distillery waste compost stability and soil type on soil carbon dynamics in amended soils. Waste Management. 30(10): 19661975.

Chen M., Xua P., Zeng G., Yang C., Huang D. and Zhang J. 2017. Bioremediation of soils contaminated with polycyclic aromatic hydrocarbons, petroleum, pesticides, chlorophenols and heavy metals by composting: Applications, microbes and future research needs. Biotechnology Advances. $\mathrm{xxx}-\mathrm{xxx}$.

Eghball B. and Gilley J.E. 1999.Phosphorus and nitrogen in run-off following beef cattle manure or compost application. Journal of Environment Quality.28: 1201-1210.

Gallardo-Larva F. and Nogades R. 1987.Effect of application of town refuse compost on the soil plant systemA review. Biological Wastes. 19:35-62.

Gill S.S., 2017. Possible Solutions to Crop Residue Burning. The Wire.

Jackson, M.L. 1973. Soil Chemical Analysis. Prentice Hall of India Pvt. Ltd., New Delhi, Pp. 498.

John M.K., 1970.Calorimetric determination of phosphorous in soil and plant materials with ascorbic acid. Soil Sciences. 109: 214-220.

Parkinson R., Gibbs P., Burchett S., Misselbrook T. 2004.Effect of turning regime and seasonal weather conditions on nitrogen and phosphorus losses during aerobic composting of cattle manure. Bioresouce Technology. 91: 171-178

Pedra F., Polo A., Ribeiro A. and Domingues H. 2007. Effects of Municipal Solid Waste Compost and Sew-age Sludge on Mineralization of Soil Organic Matter. Soil Biology and Biochemistry. 39: 1375-1382.

Reinhard T.E., Ottmar R.D. and Castillo C. 2001.Smoke impacts from agricultural burning in a rural Brazilian town. Journal of Air \& Waste Management Association. 51: 443-450.

Sadaf J., Shah G.A., Shahzad K., Ali N., Shahid M., Ali S., Hussain R.A., Ahmed Z.I., Traore B., Ismail M.I., Rashid M.I. 2017. Improvements in wheat productivity and soil quality can accomplish by co-application of biochars and chemical fertilizers. 
Science of the Total Environment.607608, 715-724.

Saha N.K., Balakrishnan M. and Batra V.S. 2005. Improving industrial water use: case study for an Indian distillery. Resources Conservation Recycling. 43: 163-174.

Shin H.S., Bae B.U., Lee J. and Paik B.C. 1992.Anaerobic digestion of distillery wastewater in a two-phase UASB reactor system. Water Science Technology. 25 (7): 361-371.

Siddiqui Y., Meon S., Ismail R. and Ali A. 2008. Bio-efficiency of compost extracts on the wet rot incidence, morphological and physiological growth of okra (Abelmoschus esculentus [(L.) moench]). Scientia Horticulture.117: 9-14.

Sidhu B.S., Beri V., Singh J. and Pannu R.P.S. 2003.Crop residues and their utilization for crop production. In: Recycling of rural and urban wastes a review. Department of Soils, PAU, Ludhiana, pp.1-35.

Srivastava S., Chopra A.K. and Pathak C. 2012. Ferti-irrigational impact of distillery effluent and Di-ammonium phosphate on the soil and growth characteristics of Eggplant (Solanum melongena L.). Journal of Applied and Natural Sciences. 4(2): 275-283.

Tahir M., Arshad M., Naveed M., Zahir Z.A., Shaharoona B. and Ahamad R. 2006. Enrichment of recycled organic waste with $\mathrm{N}$ fertilizer and PGPR containing ACC-deaminase for improving growth and yield of tomato. Soil and Environment. 25: 105-112.

Uppal J., 2004.Water utilization and effluent treatment in the Indian alcohol industry an overview. In: Liquid Assets, Proceedings of Indo- EU workshop on Promoting Efficient Water Use in Agrobased Industries. TERI Press, New Delhi, India, pp. 13-1s9.

\section{How to cite this article:}

Pankaj Kumari, Suman Chaudhary, Tanvi, Rinku Dhanker and Sneh Goyal. 2018. Evaluation of Quality Compost Prepared from Paddy Straw and Distillery Effluent for Effect on Growth of Wheat (Triticum aestivum). Int.J.Curr.Microbiol.App.Sci. 7(04): 1154-1163. doi: https://doi.org/10.20546/ijcmas.2018.704.127 